\title{
Sodium Barbital Induced Biochemical, Histological and Histochemical Changes in the Liver of Albino Mouse
}

\author{
Shadia Ali Radwan*, Aziza M. El-Wessemy*, Samia M. Sakr* \\ and Samira E. El-Harras** \\ * Department of Biological Sciences, Faculty of Education, Ain Shams University, \\ Cairo, Egypt. ${ }^{* *}$ High Institution of Applied arts, $6^{\text {th }}$ October City
}

\begin{abstract}
Introduction:The present work was planned to assess and evaluate some physiological parameters, histopathological and histochemical impacts of sodium barbital on the liver of adult male albino mice.

Material and Methods :The mice were divided into 3 groups, the first group served as a control group, while the other two groups were treated with the therapeutic dose $(60 \mathrm{mg} / \mathrm{kg}$ b.wt., i.p.) for 7 days (short-term group) and 21 days (long-term group) as repeated daily doses.

Results: Biochemical analysis showed a significant increase in serum glucose level (hyperglycaemia), AST, ALT and bilirubin, in all treated groups. Also, total lipids and triglycerides showed a significant increase in the long-term group and non significant change in the short-term group. On the other hand, alkaline phosphatase ALP, showed a significant decrease in both treated groups. Total cholesterol level showed a significant decrease in the short-term group but exhibited a significant increase in the long-term group. The results obtained from the present study showed marked alterations in the liver tissue. Histopathological changes in liver tissue were congestion of the central veins, wedening of the blood sinusoids, activation of the phagocytic küpffer cells and cytoplasmic degeneration (fatty and hydropic) with nuclear lesions. Histochemical changes in liver tissue revealed depletion of polysaccharides and total proteins in both short-term and long-term groups.

Conclusion So these results came to conclusion that barbiturates should be prohibited and carefully used specially when prescribed as tranquilizer.
\end{abstract}

Key words : Barbital, Serum, Liver functions, Histopathology, Histochemistry.

\section{Introduction}

Barbiturates gained a wide usage as tranquilizers, sedatives and hypnotics. Therefore barbiturates are widely prescribed where a general depression of nervous system activity is described. Mansour et al. (1995) studied the effect of oral administration of phenobarbitone (PB) and/or alcohol and the drug withdrawal on transaminases in blood and liver of albino rat. The animals were given $25 \mathrm{mg} / \mathrm{kg}$.b.wt. in the $1^{\text {st }}$ week, then $37.5 \mathrm{mg} / \mathrm{kg}$.b.wt. in the $2^{\text {nd }}$ week and $50 \mathrm{mg} / \mathrm{kg}$ b.wt. in the $3^{\text {rd }}$ week. Phenobarbitone (PB) administration decreased hepatic ALT activity after $1^{\text {st }}$ week, which increased with continuous PB treatment. The effect persisted showing high significant increase in hepatic ALT activity after $1^{\text {st }}$ week, which increased with continuous PB treatment. Following with, high significant increase in hepatic ALT after PB withdrawal. Also, Khalil (2000), studied the effect of phenobarbital on the serum and liver alkaline phosphatase of albino rats. The animals received low dose (68.18 mg/kgb.wt.) and high dose (136.36 $\mathrm{mg} / \mathrm{kgb}$.wt.) for several periods exhibited significant increase of serum alkaline phosphatase activity in all treated groups, while the liver alkaline phosphatase activity was significantly decreased in those treated rats.

Infante et al. (1971) found that treatment of rats with phenobarbitone increased 


\section{Shadia Ali Radwan et al}

hepatic microsomal phosph-olipids by inhibiting the catabolism rather than by stimulating its synthesis in the liver of treated animals. According to Abernethy and Azornoff (1977), Abdel-Raheem et al. (1990) a significant increase in the levels of total lipids and triglycerides was recorded in most of examined tissues of senile rats after treatment with barbitone sodium, which appear to be significant declines in blood. However, the levels of phospholipids and cholesterol exhihited decreases in all examined tissues except in testis. Recent work of El-Yamany et al. (2002), showed that intraperitoneal inject-ion $(50 \mathrm{mg} /$ kg.b.wt.) of phenobarbital for 3 weeks revealed marked increases in the concentrations of total lipids triglycerides and cholesterol in both serum and liver.

Bailey and Flatt (1980) and Mayer et al. (1983) showed that glucose tolerance is impaired during repeated administration of phenobarbital treatment lowered the insulin concentration in mice and rats. Also, Concomitant studing of El-Yamany et al. (2002) revealed a significant decrease in the serum glucose level and the activity of hepatic glucose - 6- phosphatase and lactate dehydrogenase (LDH) of rats after treatment with phenobarbital for 3 weeks.

Rice et al. (1994) and Whysoner et al. (1996) postulated that chronic exposure to high dose of PB caused hepatocellular adenomas in both rats and mice, and hepatocellular carcinomas in some strains of mice. They added that PB inhibits cell to cell communication, induces enzymes, including P 450 cytochrome, stimulates proliferation and inhibits apoptosis of hepatocytes in neoplastic foci. Sanad et al. (1997b) investigated the histopathologic effect of Sodium barbitone on the liver of mice which received intraperitoneal 51.6 or $103.2 \mathrm{mg} / \mathrm{kg}\left(1 / 8\right.$ or $1 / 4 \mathrm{LD}_{50}$ respectively) and showed apparent signs of degenerative changes designated by impairment of the normal structural organization of the hepatic lobules.

Histochemical studies of Mayer et al. (1983), showed that phenobarbital treatment induce significant decrease in glycogen synthetase in rat liver. Likewise, significant decrease was detected in serum glucose level, the activity hepatic glucose -6- phosphatase and serum lactate dehydrog-enase (LDH) were detected in albino rats after PB treatment (El-Yamany et al., 2002). Concomitant study of Sanad et al., (1997b) investigated the effect of sodium barbitone on the glycogen content in liver of mice. The adult males were injected daily (i.p.) with 51.6 and $103.2 \mathrm{mg} / \mathrm{kg}$ b.wt. of sodium barbitone for various periods. The liver cells of treated animals showed progressive diminution of glycogen content which was more obvious on using the higher dose. This work aimed to examin the possiblity side effects of the ubuse of sodium barbital on essential target organ (the liver).

\section{Material and Methods}

\section{Chemicals}

Barbital sodium $\left(\mathrm{C}_{8} \mathrm{H}_{11} \mathrm{~N}_{2} \mathrm{NaO}_{3}\right)$

[Merck - CAS.No. 144.02 - 5 - white crystalline powder] with trade name, veronal was used in this study. For mice, the effective therapeutic dose was calculated relevant to the human therapeutic dose $(60 \mathrm{mg} / \mathrm{kg}$.b.wt.) and according to the body weight and body surface area (Gilman et al., 2000).

\section{Animal groups and experimental design}

Thirty male albino-mice weighing approximately $25-30 \mathrm{~g}$, were used in the present study; the animals were divided into 3 groups, 10 animals for each, assigned as follows :

Control group : Animals were intraperitoneal injected with $(0.9 \%$ sodium chloride $\mathrm{NaCl}$ ).

Short-term group : Each animal was i.p. injected with a daily dose of 60 $\mathrm{mg} / \mathrm{kg}$.b.wt. of sodium barbital for 7 successive days.

Long-term group : Each animal was i.p. injected with a daily dose of 60 $\mathrm{mg} / \mathrm{kg}$.b.wt. of sodium barbital for 21 successive days.

After the end periods of treatment, the animals of each group were decapitated. Blood sera and liver samples were collected for physiological, histological \& histochemical preparations. 
Serum AST and ALT activities was determined according to Reitman \& Frankel (1957). Serum alkaline phosphatase (ALP) activity was determined according to Belfield \& Godberg (1971). Serum total bilirubin was determined colorimetrically according to Smis \& Horn (1958). Serum total lipids levels was determined colorimetric using the kit of Randox lab. Ltd., measured at $546 \mathrm{~nm}$ and expressed as $\mathrm{mg} / 100 \mathrm{ml}$ according to Zollner and Kirsch (1962). Serum triglycerides levels was determined according to Wienland (1974). Serum total cholesterol level was determined according to Flegg (1973). Serum glucose concentration was determined according to Trinder (1969). For histological and histochemical preparations, specimens of liver were fixed in Bouin's (polysaccharides preparations) or Carnoy's fixative (total proteins preparations). The specimens were then dehydrated, cleared embedded in paraffin wax, sectioning and stained with haematoxylin and eosin. For demonstration of polysaccharides, PAS technique using periodic acid and Schiff's reagent (Pearce, 1972) was applied. For demonstration of total proteins, mercury bromophenol technique (Mazai et al., 1953) was applied. The obtained data were statistically analysed using Primar of Biostatistics (A computer program specialized in performing statistical analysis), in which the equation of the hypothesis test, including standard deviation, t-statistics value and probability $(\mathrm{P})$ were used. Significant results were considered at $p<0.05$, highly significant at $\mathrm{P}<0.01$ and very highly significant at $\mathrm{P}<0.001$ according to Glantz (1992).

\section{Results}

The current study revealed a very highly significant increase $(\mathrm{P}<0.001)$ in AST activity with a change $57.06 \%$ and $100.57 \%$ and ALT activity with a change $80.16 \%$ and $160.6 \%$ respectively in both short term and long term groups respectively. However, ALP activity recorded a highly significant decrease $(\mathrm{P}<0.01)$ in short term group $(-15.1 \%)$ and a very highly significant decrease $(\mathrm{P}<0.001)$ in the long term group (-37.24\%) when compared to the control group (Table 1, figure 1a). Meanwhile, table (1) figure (1b) showed that the bilirubin content was highly significant increased $(\mathrm{P}<0.001)$ in short term group $(50 \%)$, while sodium barbital treatment induced a significant increase $(\mathrm{P}<0.05)$ in the long term group $(37.5 \%)$. Inspection of the table (2) and figure (2) revealed non significant change in total lipids content after short term period $(4.70 \%)$. On the other hand, the repeated doses of sodium barbital for 21 days (long term) caused a very highly significant increase $(\mathrm{P}<0.001)$ in total lipids $(52.06 \%)$. However, triglycerides content recorded non significant change and very highly significant increase $(\mathrm{P}<0.001)(138.89 \%)$ in short term and long term groups respectively. The repeated doses of sodium barbital caused a very highly significant decrease $(\mathrm{P}<0.001)$ of cholesterol level $(-47.50 \%)$ in short term group compared with the control group. On the other hand, very highly significant increase $(\mathrm{P}<0.001)$ of serum cholesterol level (61.69\%) was noticed in the long term group compared with the control group. Concerning the serum glucose level, the data in table (3) and figure (3) revealed a highly significant increase $(\mathrm{P}<0.01)(14.183 \%)$ after 7 days of treatment and a very highly significant increase $(P<0.001)$ in serum glucose level reaching $160.94 \%$ after 21 days of sodium barbital treatments.

\section{Histological and Histochemical studies}

Microscopic examination of the liver of sodium barbital - treated mice (Plate1, Figs. 6-9) revealed many histopathological alterations (which are directly correlated with the increase of treatment) when compared with the control group (Plate 1, Figs. $4 \& 5$ ). One week post-treatment with $60 \mathrm{mg} / \mathrm{kg} / \mathrm{b} / \mathrm{wt}$. of sodium barbital (sections of liver) reflected signs of injury as indicated by degeneration with damaged nuclei including some pyknotic nuclei. Some hepatic cells were characterized by their degenerated cytoplasm. Furthermore, some of these degenerated hepatocytes had deteriorated nuclei with distinct features of 


\section{Shadia Ali Radwan et al}

karyorrhexis $(\mathrm{kx})$ while in some other cells, the nuclei were obviously karyolysed. Küpffer cells $(\mathrm{kc})$ were actively proliferating, increased in size, appeared irregularly elongated and some of them were pushed into the sinusoidal lumens. However, the vacuolation of the cytoplasm is so extensive to the extent that only a very limited portion of it was left. Congestion appeared in the branches of the hepatic portal vein and the bile duct (bd) which were infiltrated and surrounded by inflammatory cells (Plate 1, Figs. $6 \&$ 7). Examination of liver sections of mice treated daily with $60 \mathrm{mg} / \mathrm{kg}$.b.wt. of sodium barbital for three weeks revealed severe pathological alterations in the hepatic tissue (Plate 1, Figs. 8 \& 9). Some hepatocytes reflected more advanced degree of injury as indicated by fatty degeneration with nuclei showing karyorrhexis and stages of karyolysis. In addition, some of the hepatocytes were degenerated, the cell membranes of most hepatic cells were disrupted and the cytoplasm of other cells lost their normal characteristics. The hepatic sinusoids were dilated and invaded with lymphocytic inflammatory cells. In addition, küpffer cells $(\mathrm{kc})$ were markedly increased in size, being more or less oval or triangular in shape, they were activated and pushed into the sinusoidal lumens. Thickened wall of the bile duct was detected. Congestion (C) of the hepatic portal vein was also observed (Plate 1, Figs 8\& 9).

For the histochemical studies of polysaccharides, (plate 2, figure 10 revealed the existence of considerable amounts of glycogen inclusions in the hepatocytes of control mouse. The daily application of $60 \mathrm{mg} / \mathrm{kg} . \mathrm{b}$.wt of sodium barbital for one week caused a noticeable loss of polysaccharides in the hepatocyte components (Plate 2, Figure 11). Such loss was indicated by relative diminution of PAS +ve stainability. The general picture of glycogen loss was quite evident in almost all hepatocytes, as demonstrated in plate 2, figure 11 , but exceptionally marked signs of PAS +ve reactivity were still sporadically met within some tissue due to the existence of glycogen material in these degenerated and necrotic areas. Long-term treatment with sodium barbital had obviously accentuated the magnitude of delineated PAS +ve reactivity in hepatic tissues as demonstrated in plate 2, figure 12 . In general, a weak to slightly moderate PAS +ve reactivity was visualized in these specimens but in a rather non-homogeneous manner. Worthwhile, is that such dominated reactivity was more accentuated in the pericentrally lobular cells.

For histochemical detection of total proteins content, Plate 2, Figure 13 revealed the total proteins in the liver section of control mouse in the form of bluish granules of various sizes distributed randomly in the ground cytoplasm. The cells as well as the nuclear membranes have acquired an intense stainability in these preparations denoting their richness in protein inclusions. Besides, both chromatin bodies and nucleoli exhibited a deep colouration with bromophenol blue stain. One week following the daily application of the dose $60 \mathrm{mg} / \mathrm{kg}$.b.wt., liver section of sodium barbital - treated mouse revealed a diminished reactivity for protein material in both hepatocytes and their nuclei, as demonstrated in plate 2, figure 14. Liver tissue had obviously responded to this treatment by a prominent decline in their proteinic inclusion. The liver cells were also characterized by vacuolated cytoplasm. The proteinic remnants were obviously less reactive with bromophenol blue than control, but most of the vacuolar areas were colourless (Plate 2, Figure 14). After three weeks of treatment, loss of proteinic material seemed to have occurred in the majority of the liver tissue. Hepatocytes acquired vacuolar spaces and completely lacked the presence of positive protein staining. In addition, nuclei, of such cells exhibited partial clumping of protein material which scattered within the nuclei. The dilated simusoidal spaces were also devoid of stainable material. The hepatic central vein was occupied by degenerated proteinic material (plate 2, Figure 15). 
Table (1): The effect of sodium barbital $60 \mathrm{mg} / \mathrm{kg}$ for $7 \& 21$ successive days on serum transaminases (AST, ALT), and (ALP)activities and Bilirubin content of mice.

\begin{tabular}{|c|c|c|c|c|c|c|c|c|}
\hline \multirow[b]{2}{*}{ Groups } & \multicolumn{2}{|c|}{ AST (U/L) } & \multicolumn{2}{|c|}{ ALT (U/L) } & \multicolumn{2}{|c|}{ ALP (U/L) } & \multicolumn{2}{|c|}{ Bilirubin (mg / ml) } \\
\hline & $\mathrm{Mean} \pm \mathrm{SD}$ & $\begin{array}{c}\% \\
\text { Change }\end{array}$ & Mean \pm SD & $\begin{array}{c}\% \\
\text { Change }\end{array}$ & $\mathrm{Mean} \pm \mathrm{SD}$ & $\begin{array}{c}\% \\
\text { Change }\end{array}$ & Mean \pm SD & $\begin{array}{c}\% \\
\text { Change }\end{array}$ \\
\hline Control & $208.3 \pm 16.776$ & & $\frac{35.3 \pm 7.36}{6}$ & & $298 \pm 9.143$ & & $0.40 \pm 0.07$ & \\
\hline $\begin{array}{c}\text { Short term } \\
1^{\text {st }} \mathrm{W} . \\
\text { group }\end{array}$ & $327.16 \pm 33.902$ & $\begin{array}{c}57.06 \\
* * *\end{array}$ & $63.6+7.96$ & $\begin{array}{c}80.16 \\
* * *\end{array}$ & $253 \pm 30.272$ & $\begin{array}{c}-15.1 \\
* *\end{array}$ & $0.60+\frac{ \pm}{2} 0.13$ & $\begin{array}{l}50 \\
* *\end{array}$ \\
\hline $\begin{array}{l}\text { Long term } \\
3^{\text {rd }} \mathrm{W} . \\
\text { group }\end{array}$ & $417.8+38.535$ & $\begin{array}{c}100.57 \\
* * *\end{array}$ & $92+4.560$ & $\begin{array}{c}160.623 \\
* * *\end{array}$ & $187 \pm 12.312$ & $\begin{array}{c}-37.24 \\
* * *\end{array}$ & $0.55 \frac{+0}{2} \cdot 10$ & $\begin{array}{c}37.5 \\
*\end{array}$ \\
\hline
\end{tabular}

*Significant $(\mathrm{P}<0.05)$

**Highly significant $(\mathrm{P}<0.01)$

$* * *$ Very highly significant $(\mathrm{P}<0.001)$

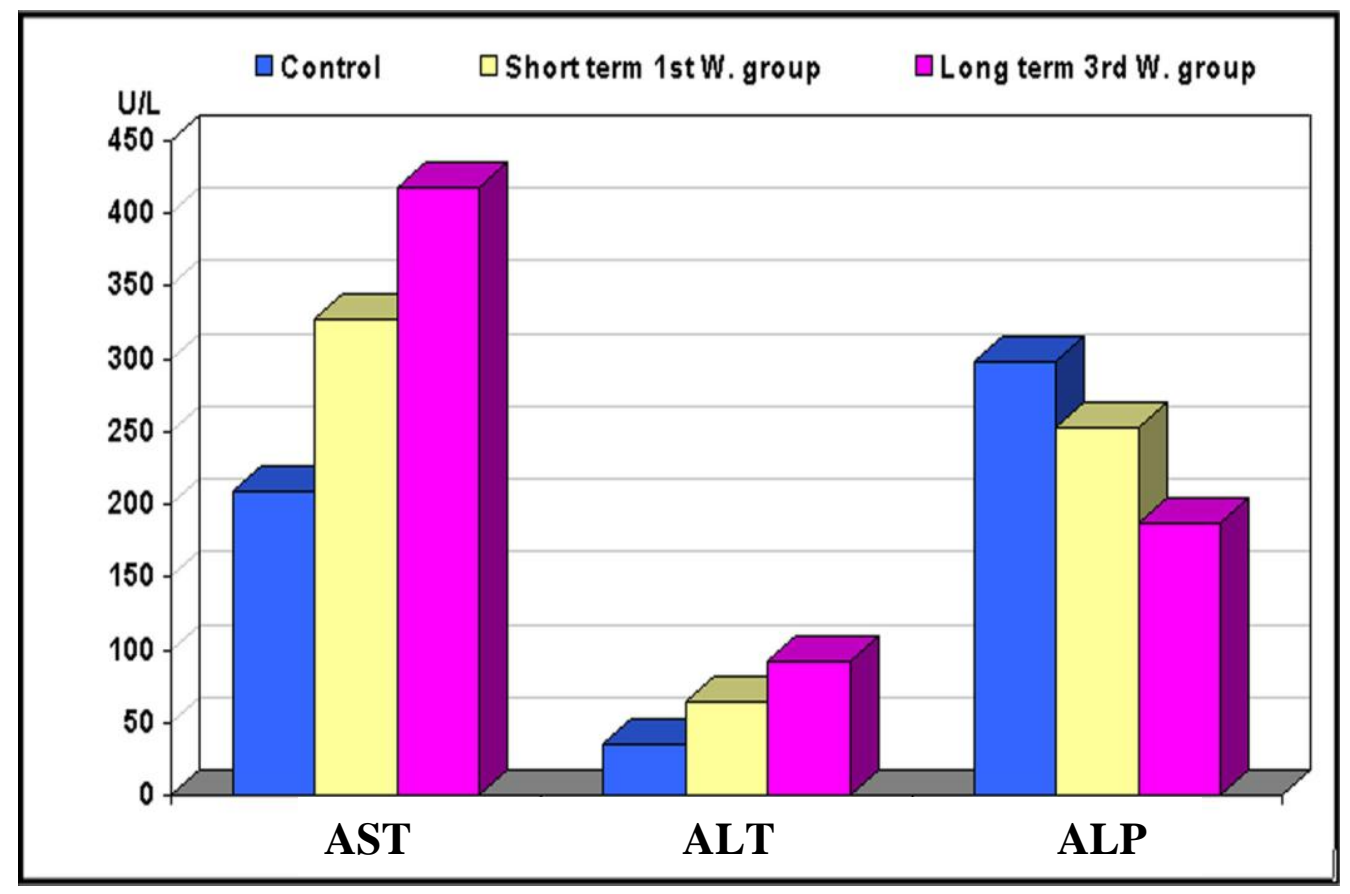

Figure (1a): The effect of sodium barbital $60 \mathrm{mg} / \mathrm{kg}$ for $7 \& 21$ successive days on the activity of serum transaminases (AST, ALT) and ALP of mice. 


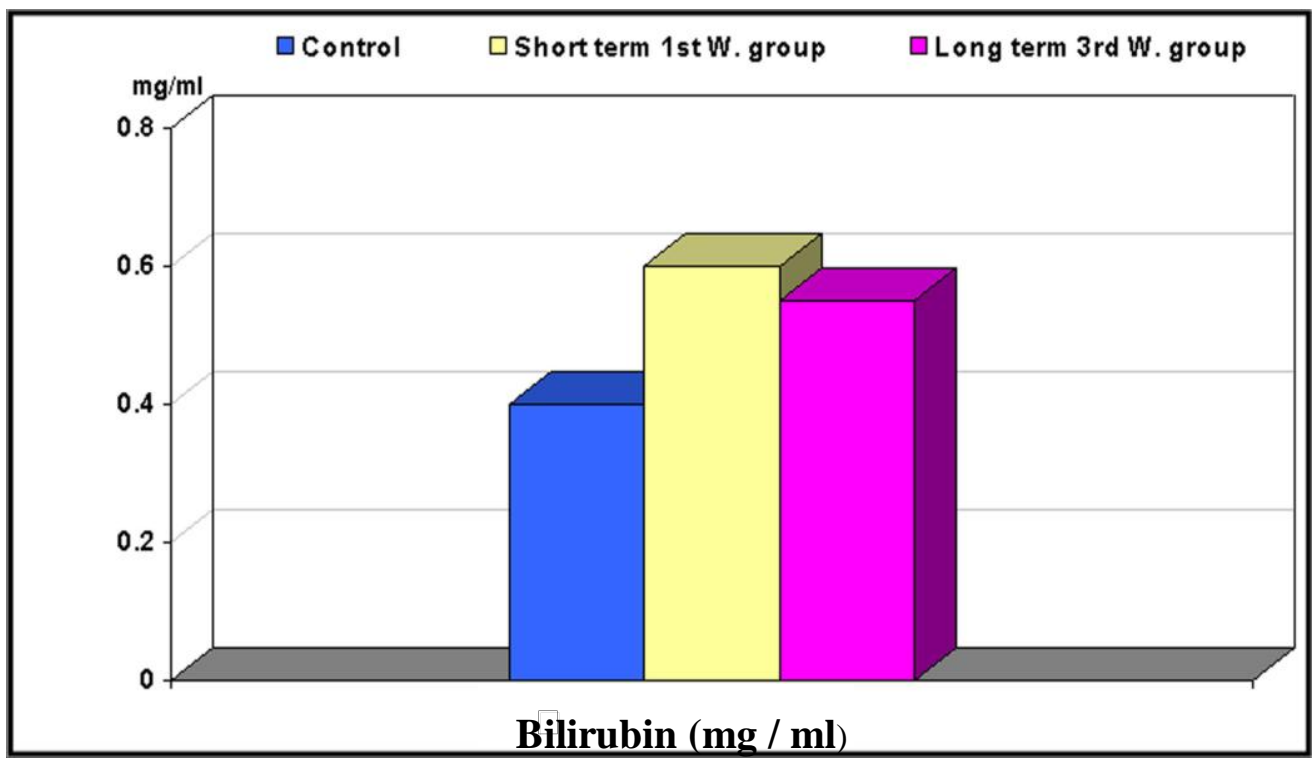

Figure (1b) : The effect of sodium barbital $60 \mathrm{mg} / \mathrm{kg}$ for $7 \& 21$ successive days on serum Bilirubin of mice.

Table (2): The effect of sodium barbital $60 \mathrm{mg} / \mathrm{kg}$ for $7 \& 21$ successive days on the serum levels of total lipids $(\mathrm{mg} / \mathrm{ml})$, triglycerides $(\mathrm{mg} / \mathrm{ml})$ and cholesterol $(\mathrm{mg} / \mathrm{ml})$ of mice.

\begin{tabular}{||c||c|c||c|c||c|c||}
\hline \hline \multirow{2}{*}{ Groups } & \multicolumn{2}{|c||}{ Total lipids (mg/ml) } & \multicolumn{2}{c||}{ Triglycerid (mg/ml) } & \multicolumn{2}{c||}{ Cholesterol (mg/ml) } \\
\cline { 2 - 6 } & Mean+SD & \% Change & Mean+SD & $\%$ Change & Mean+SD & Change \\
\hline \hline Control & $290.33 \pm 20.06$ & & $74.3 \pm 15.396$ & & $182.5 \pm 34.291$ & \\
\hline $\begin{array}{c}\text { Short term } 1^{\text {st }} \\
\text { W. group }\end{array}$ & $304 \pm 59.48$ & 4.70 & $75.5 \pm 16.908$ & 1.61 & $95.83 \pm 12.66$ & $-47.50 * * *$ \\
\hline $\begin{array}{c}\text { Long term } 3^{\text {rd }} \\
\text { W. group }\end{array}$ & $441.5 \pm 53.091$ & $52.06 * * *$ & $177.5 \pm 25.28$ & $138.89 * * *$ & $295.17 \pm 20.66$ & $61.69 * * *$ \\
\hline
\end{tabular}

* Significant $(\mathrm{P}<0.05)$

** Highly significant $(\mathrm{P}<0.01)$

*** Very highly significant $(\mathrm{P}<0.001)$ 
Sodium Barbital Induced Biochemical, Histological.........

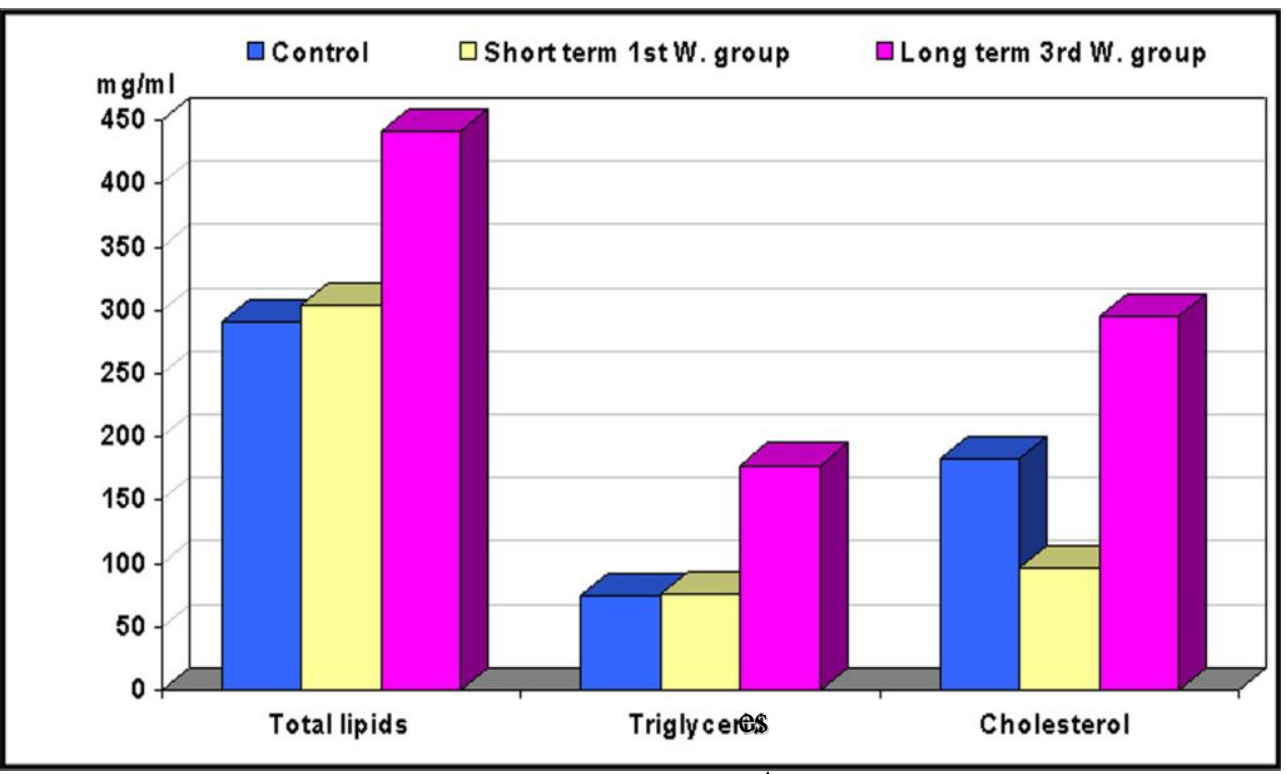

Figure (2): The effect of sodium barbital $60 \mathrm{mg} / \mathrm{kg}$ for $7 \& 21$ successive days on the serum levels of total lipids $(\mathrm{mg} / \mathrm{ml})$, triglycerides $(\mathrm{mg} / \mathrm{ml})$ and cholesterol $(\mathrm{mg} / \mathrm{ml})$ of mice.

Table (3) : The effect of sodium barbital $60 \mathrm{mg} / \mathrm{kg}$ for $7 \& 21$ successive days on serum glucose level $(\mathrm{mg} / 100 \mathrm{ml})$ of mice.

\begin{tabular}{|l|c||c||}
\hline Groups & Mean \pm SD & \% Change \\
\hline \hline Control & $70.83 \pm 11.070$ & \\
\hline Short term $1^{\text {st }} \mathrm{W}$. group & $100 \pm 17.753$ & $41.183^{* *}$ \\
\hline Long term $3^{\text {rd }} \mathrm{W}$. group & $184.83 \pm 20.22$ & $160.94^{* * *}$ \\
\hline
\end{tabular}

* Significant $(\mathrm{P}<0.05)$

** Highly significant $(\mathrm{P}<0.01)$

*** Very highly significant $(\mathrm{P}<0.001)$

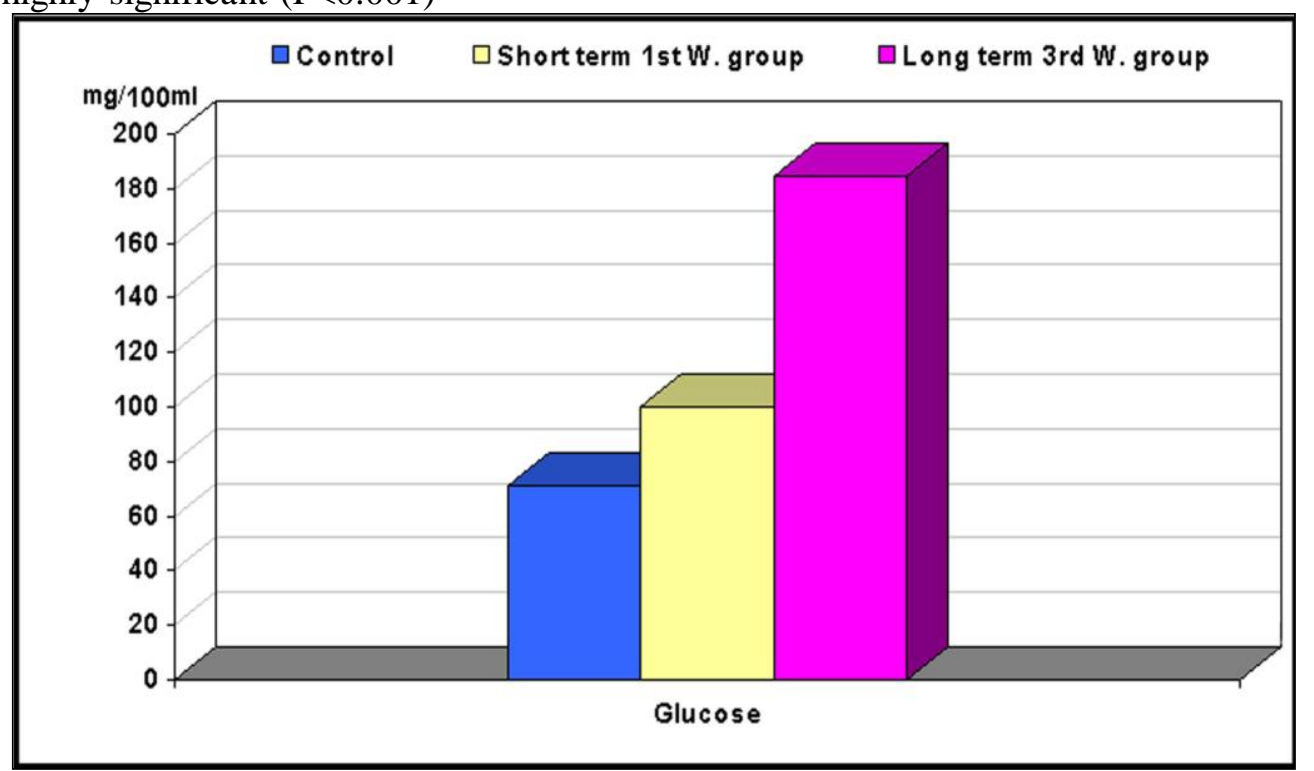

Figure (3) : The effect of sodium barbital $60 \mathrm{mg} / \mathrm{kg}$ for $7 \& 21$ successive days on serum glucose level $(\mathrm{mg} / 100 \mathrm{ml})$ of mice. 


\section{Shadia Ali Radwan et al}

\section{Explanation of figures}

\section{Plate (1)}

Bouin-fixed paraffin sections of the liver of mice, stained with haematoxylin and eosin.

Fig. (4) : Photomicrograph of a section of the liver of a control mice, showing the central region of a hepatic lobule. The hepatocytes surround the central vein $(\mathrm{CV})$ and the blood sinusoids (BS) are seen between the hepatic strands. küpffer cells (KC) intervene the walls of the sinusoids. Notice the bile canaliculi (be) between the hepatic cells (X: 400).

Fig. (5) : Photomicrograph of the liver of mice, showing a portal area contain a branch of the hepatic portal vein (HPV), a hepatic artery (HA) and a bile ductule (bd) (X: 225).

Fig. (6) : Photomicrograph of a section of the liver of mice, treated with $60 \mathrm{mg} / \mathrm{kg}$ b.wt of sodium barbital for one week, showing congestion in the hepatic portal vein and the bile duct (bd), cytoplasmic degeneration and karyolysis of nuclei in some cells (X: 225).

Fig. (7) : Photomicrograph of a section of the liver of mice, treated with $60 \mathrm{mg} / \mathrm{kg}$ b.wt. of sodium barbitone for one week, showing congestion of blood vessel (CV), fatty degeneration and karyolysis of some nuclei (arrow) and activation of küpffer cells (KC) (X: 400),

Fig. (8) : Photomicrograph of a section of the liver of mice, treated with $60 \mathrm{mg} / \mathrm{kg}$ b.wt. of sodium barbital for three weeks, showing congestion (C)of a hepatic vein, fatty degeneration with deteriorated nuclei in some cells and thickened wall of the bile ductule (bd). (X: 225).

Fig. (9) : Photomicrograph of a section of the liver of mice, treated with $60 \mathrm{mg} / \mathrm{kg}$ b.wt. of sodium barbital for three weeks, showing congestion of the central vein $(\mathrm{CV})$, degeneration of hepatocytes with deteriorated nuclei and dilatation of hepatic sinusoids invaded with lymphocytes and activated küpffer cells

Plate (2)

Bouin-fixed paraffin sections of the liver of mice, stained in PAS for the demonstration of polysaccharides.

Fig. (10) : Photomicrograph of a section of the liver of a control mice, showing carbohydrate material (glycogen) in the ground cytoplasm of the hepatocytes. The glycogen appears as bodies located mainly at one pole of the cell reflecting the phenomenon of glycogen flight (X: 225).

Fig. (11) : Photomicrograph of a section of the liver of mice, treated with $60 \mathrm{mg} / \mathrm{kg}$ b.wt. of sodium barbital for one week, showing depletion of general carbohydrate (glycogen) (X:225).

Fig. (12) : Photomicrograph of a section of the liver of mice, treated with $60 \mathrm{mg} / \mathrm{kg}$ b.wt. of sodium barbital for three weeks, revealing more glycogen depletion with non homogenous distribution of glycogen (A: 225).

Carnoy-fixed paraffin sections of liver of mice, stained in bromophenol blue stain for general proteins.

Fig. (13) : Photomicrograph of a section of the liver of control mice, revealing moderate to rather strong protein reactivity in the hepatocyts and their nuclei (X: 660).

Fig. (14) : Photomicrograph of a section of the liver of mice, treated with $60 \mathrm{mg} / \mathrm{kg}$ b.wt. of sodium barbital for one week, revealing reduced protein stainability in the hepatic cells. Notice clumping of protein material scattered within nuclei (X: 660).

Fig. (15) : Photomicrograph of a section of the liver of a mice, treated with $60 \mathrm{mg} / \mathrm{kg}$ b.wt. of sodium barbital for three weeks, showing reduced protein stainability in the liver tissues, this reduction was clear in the ground cytoplasm than in the degenerated products (X:660). 
Plate (1)
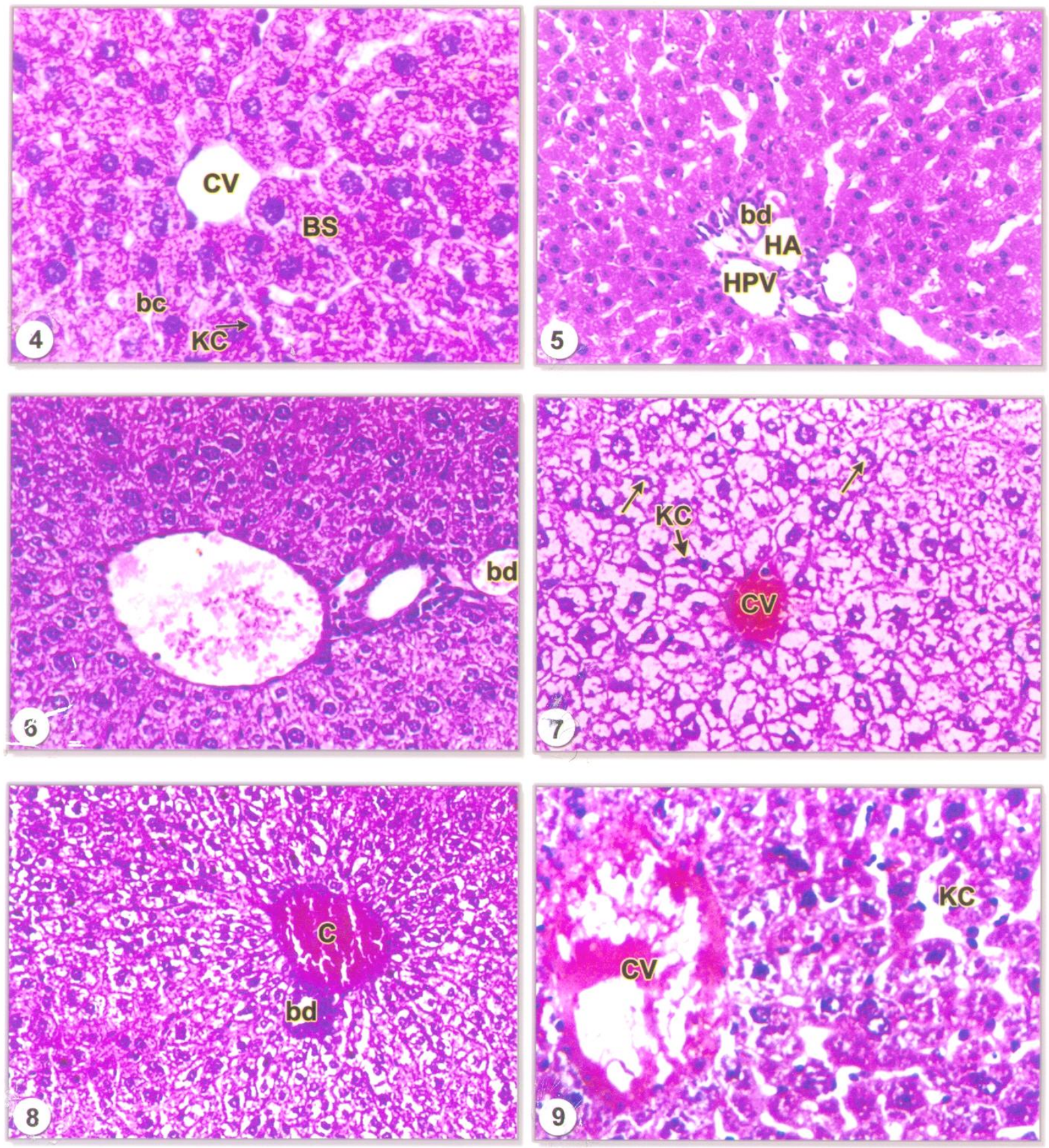
Plate (2)
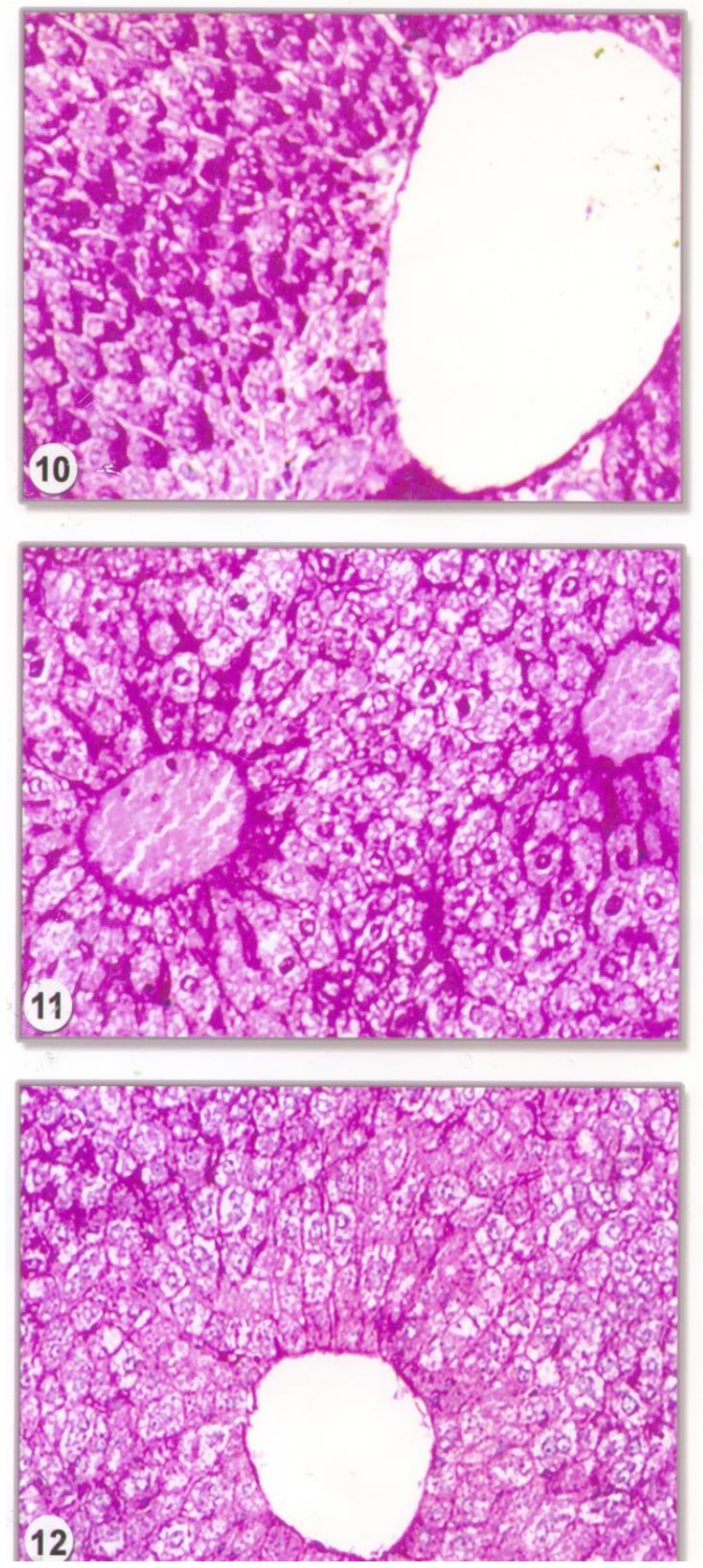

Plate (3)
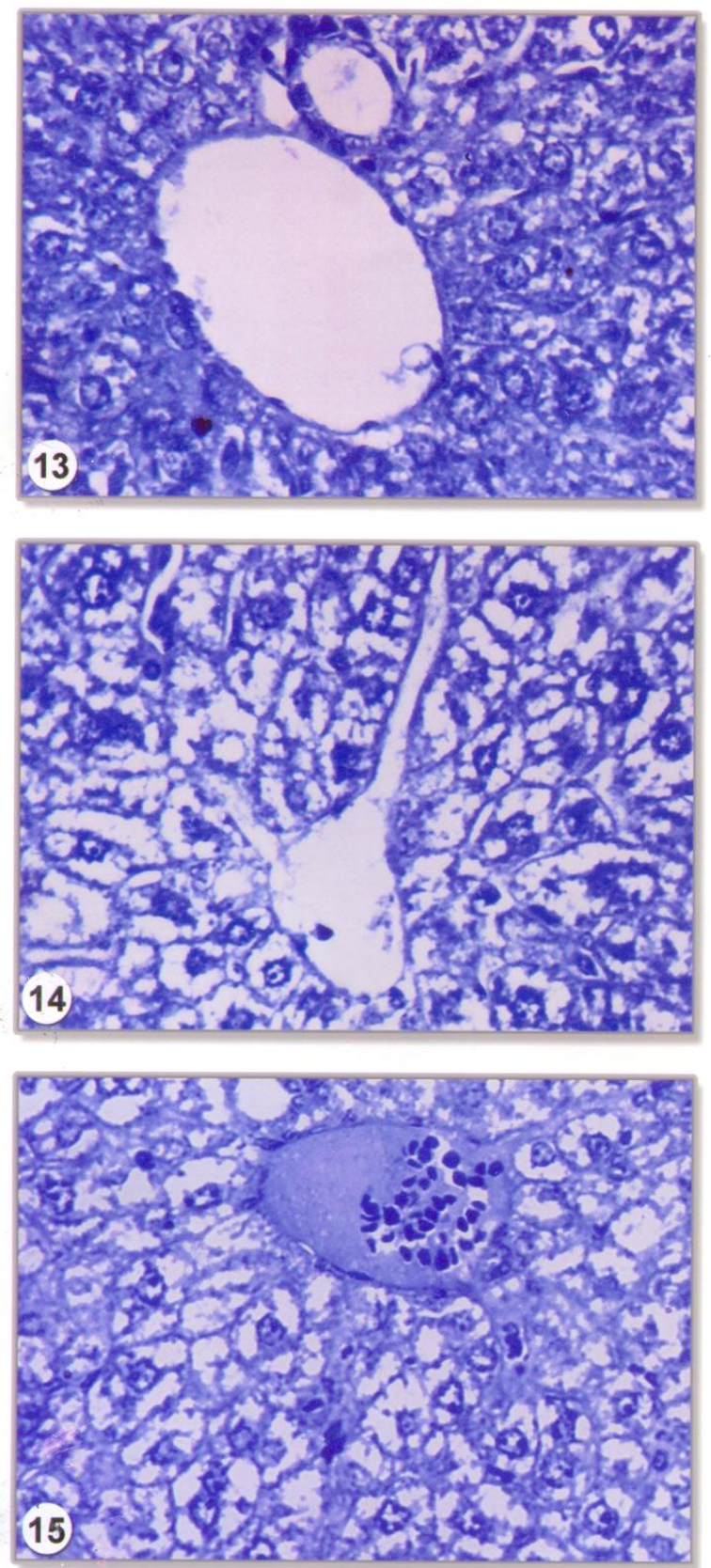


\section{Discussion}

The present study showed very highly significant increase of AST and ALT in all treated groups, these results are in agreement with Martin et al. (1983) and Wahbi et al. (1987). On the other hand, alkaline phosphatase activity showed a significant decrease in both treated groups. Bilirubin content showed a highly significant increase in shortterm group and significantly increase in longterm group. Martin et al. (1983) announced that liver tissues which may famous for their rich contents of transaminases (ALT and AST) suffer from their loss under many pathologic conditions. This ultimately leads to their raised levels in the sera of these animals. Hence, they suggested that the higher values of these enzymes in the blood sera should be taken as an indication of various degenerative events in the liver. It has been found that the serum ALT is raised only when cells of the liver parenchyma were destroyed while, the rise in serum AST may be due to cellular destruction in several extra-hepatic tissues (Wahbi et al., 1987). Ahn et al. (1998), reported that the increase in serum enzymes may be a consequent of increased lipid peroxidation and membrane damage. Lipid peroxidation is caused by the dangerous effect of free radicals (reactive species having unpaired electron) on target tissue. The formation of highly reactive free radicals as a result of chemical agent (carbon tetrachloride) metabolism by the liver cytochrome enzyme system, affects the cell constituents and cause membrane damage. El-Bolkiny (2004) attributed the decrease in ALP to the hepatocellular damage in response to the administration of narcotics and this lead to the impairment of synthesis and release of transaminases and phosphatases.

The present study showed a highly significant and very highly significant increase of serum bilirubin levels in short and long term groups respectively. One of the causes of elevated bilirubin levels is the excessive destruction of red blood cells in cases of anemia and haemolytic disease
(McClintic, 1978). Vajdovich et al. (1995) and Deshpand et al. (1998), explained the elevation in serum bilirubin by increased lipid peroxidation as well as glutathione depletion and haemoglobin catabolism resulting in less conjugated bilirubin haemoglobin by the liver due to $\mathrm{CCl}_{4}$ poisoning. This increase may be attributed to liver dysfunction, haemorrhage, inhibition of hepatic synthesis of clotting factors may be also due to excess production of bilirubin (haemolytic anemia) and decreased uptake of bilirubin into hepatic cells disturbed secretion of conjugated bilirubin into the bile canaliculi (Gomaa, 2003).

The present study revealed that sodium barbital treatment for long-term caused very highly significant increase in serum total lipids, triglycerides and cholesterol levels. This is in agreement with ElYamany et al. (2002) after phenobarbital treatment of rats. The authors attributed the increase in the serum triglycerides (TG) as a result of inhibition of lipoprotein lipase activity and also, synthesis and extrusion of TG by liver, may elevate serum TG. Elevation of serum cholesterol level by barbiturates treatment may not related to cholesterol synthesis only but also to such factors as accumulation within tissue pools, degradation and elimination which may altered by this treatment (Abu El-Zahab, 1999b).

The present investigation demonstrate a highly significant increase in the amount of the serum glucose level (hyperglycaemia in the long-term group after sodium barbital treatment. Similar results were obtained by Badr El-Din (1999) after treatment with pentobarbiton. Ismail (2005) suggested that hyperglycaemia may be due to the enhancement of the activities of the enzymes involved in glucogneogenesis e.g. pyruvate carboxylase, carboxykinase, fructose 1, 6diphosphatase and glucose -6- phosphatase leading to formation of glucose from noncarbohydrate source. According Ceron et al. (1996), hyperglycaemia may related to inhibition of cholinesterase and consequent accumulation of acetylecholine, then 


\section{Shadia Ali Radwan et al}

actylcholine stimulates the adrenal medulla to release adrenaline and consequently elevation of blood sugar level so, the possible destruction of cells of islets of Langerhans.

The present study clearly demonstrated that the injection of adult albino mice with sodium barbital induced prominent lesions in the liver tissue. The severity of these changes increases with the increasing period of administration. These lesions generally comprise tissue disorganization, congestion of blood vessels, cellular necrosis, cytoplasmic vacuolation (degeneration), accumulation of inflammatory cells especially around the portal tracts and activation and hyperplasia of küpffer cells. These observations were agree with Sanad et al. (1997a), and ElSherif et al. (2002) after treatment with sodium barbitone and morphine sulphate on the liver of mice and rats respectively. The present study showed cell necrosis in liver tissue of treated mice and this is in agreement with Levier et al. (1993) who attributed the necrosis to that pyknotic nuclei with coiling and shortening of chromosomes result in dark stained nuclei after morphine sulphate treatment. Likewise, More and Brown (1994) reported that necrosis may be due to the decrease in the blood supply to an area of tissue, while Burk et al. (1995) attributed the necrosis to the depletion of glutathione in liver tissue. Orr and Blakley (1997) considered such necrotic lesions may be either due to progressive degenerative action of intracellular enzymes of the injured cells or to the metabolic disturbance and inhibition of protein synthesis in the hepatic cells. Cytotoxic injury induced by drugs and chemicals may occasionally lead to a chronic inflammatory response characterized by accumulation of inflammatory cells (Haschek and Rousseaux, 1991). Dienes et al. (1982) suggested that the increase in size of küpffer cells and proliferation of the bile ductules reflect clearly an active defence mechanism against the toxic materials. From another point of view, other authors are of the opinion that cytoplasmic vacuolation is most probably brought about by the increase of lysosome elements (Chareonpong-Kawamoto et al. 1995). On the other hand, El-Sherif et al., (2002) concluded that the dilatation of hepatic sinusoids led to decrease in the rate of blood flow through the sinusoids and central veins which results in a decrease in blood drainage and increases congestion within blood cells.

The present study recorded a gradual depletion of charbohydrate in both treated groups, these results are in agreement with El-Banhawy et al. (1992) and Sanad et al. (1997b) after treatment with Ketalar and sodium barbital, respectively. Chareonpong. Kawamoto et al. (1995) attributed glycogen depletion after treatment with selenium to the increased activities of lysosomal enzymes. Glycogen loss under such circumstances, was given some various interpretations by different investigators. Casarette (1986) pointed out that the glycogen depletion reflects the lost capacity of cells to metabolize glycogen storage or maintenance of its storage related to the ability of the liver to neutralize drugs, thus any liver impairment would naturally affect such liver abilities.

In the present investigation, proteins have been noticed to be affected by sodium barbital in the hepatic cells of male albino mice. These tissue components exhibited a gradual diminution in those cells and go on progressively with increased duration, so our results are in agreement with Sanad et al. (1997b). To signify the close relationship between the liver and proteins, Wright et al. (1985) postulated that the liver plays a key role in the metabolism of amino acids in particular, and proteins in general. The liver is the exclusive or principal site of synthesis of virtually all the plasma proteins, as it is an important route of degradation of many of these proteins including hormones. The authors added that the liver is capable of modulating overall body protein metabolism by virtue of its role in the metabolic processes of hormones which have significant effects on the fate of amino acids in the peripheral tissues. Sanad (1997b) and Matthew and Ray (1999) indicated depletion of protein after sodium barbital and morphine administration 
respectively and attributed this to the direct proportional effect on the protein synthesis. Also, El-Sherif et al. (2002) attributed reduction in the protein content to the decreased rate of polypeptide elongation, respiratory depression and decrease of $t$ RNA in liver tissues. According to Tavill (1985), liver fibrosis is a catabolic feature associated with protein breakdown and nitrogen disbalance. Mandal et al. (1988) recorded that the inhibition of intramitochondrial protein synthesis by some antibiotics produced a decrease in protein and RNA contents in the liver cells. Meanwhile, Word et al. (1988) found that sodium barbitone induced an early transient increase in the levels of hepatocytes DNA synthesis.

In conclusion, it could be stated that sodium barbital (barbiturates) has deleterious impacts on the liver of experimental animals, both structurally and functionally, particularly when used for long duration. So, barbiturates should be used carefully when prescribed as tranquillizer (sedadives $\&$ hypnotics) drugs.

\section{References}

1. Abdel-Raheem K, Bayomy M, Shaalan $\mathbf{S}$ and Tawfik A. (1990): The effect of an overdosage of barbitone sodium on lipid metabolism in senile rats. Bull. Fac. Sci., Cairo Univ., 58: 277-289.

2. Abernethy D and Azarnoff D (1977): Effect of drugs, which alter microsomal drug-metabolizing enzyme activity on rat hepatic cholesterol biosynthesis. Biochem. Pharmacol., 26: 481-484.

3. Abo Samra WE (1997): Comparative action of $\mathrm{CCl}_{4}$ as pure chemical or dissolved in corn oil or water on some physiological and biological parameters of rats. J. Egypt. Ger. Soc. Zool., 24 (A): 135-138.

4. Abu El-Zahab H S H (1999): Effect of barbitone sodium administration on some lipid parameters of adult and old male albino rats. J. Egypt. Ger, Soc. Zool., 28(A): 317-336.

5. Ahn Bo Oh, Ty Kim, SH, Kim WB and Lee EB (1998): Studies on protective effect of DA-9601, Artemisia asiatica extract, on acetaminophen-and $\mathrm{CCl}_{4}$ - induced liver damage in rats. Arch. Pharmacol. Res., 21 (5): 508-513.
6. Amer AM (1999): Assessment of the role of doxazosin on serum lipids and lipoproteins and histopathologic effects on liver of rabbits. J. Egypt. Ger. Soc. Zool., 30(A): 231-242.

7. Badr El- Din NK (1999): Effects of panax ginseng extract on sleep and glucose homeostasis in pentobarbitone-induced anaesthesia in rats. Egypt.J. Zool., 33:331-341.

8. Bailey CJ and Flatt PR (1980): Insulin and glucagon during pentobarbitone anaesthesia. Diabetes Metab., 6 (2): 91-92.

9. Belfield A and Goldberg DM (1971): Colorimetric determination of alkaline phosphatase activity. Enzymes, 12:561-568.

10. Bhatnagar V, Farma $\mathbf{V}$ and Vara $A$ (1994): Inhibition of cholinesterase in male mice fed dichlorvos (DDVP). Indian Journal of Toxicology. (2) 49-51.

11. Burk R.F, Hill K.E, Awad JA, Morrow JD and Lyons PR (1995): Liver and kidney necrosis in selenium-deficient rats depleted of glutathione. Lab. Invest., 72(6): 723-730.

12. Casarette WO (1986): Cell injury. Proc. Soc. Exp. Biol. Med.; 91: 126-135.

13. Cerón JJ, Sancho E, Ferrando MD, Gutierrez C and Andreu E (1996): Metabolic effects of diazinon on the European eel Anguilla anguilla. J. Environ. Sci Health (B), 31 (5): 1029-1040.

14. Chareonpong-Kawamoto $\mathbf{N}$, Higasa $\mathbf{T}$ and Yasumoto K (1995): Histological study of iron deposits in selenium-deficient rats. Biosci. Biotechnol. Biochem., 59(10): 1913-1920.

15. Deshpand UR, Gadre SG, Raste AS, Pillai D, Bhide SV and Samuel AM (1998): Protective effect of Tumeric (Curcuma longa L.) extract on $\mathrm{CC}_{4}$ induced liver damage in rats. Ind. J. Exp. Biol., 36(6): 573-575.

16. Dienes HF, Popper H, Arnold W and Lobeck H (1982): Histological observations in human hepatitis. Hepatology, 2 (5): 562-571.

17. El-Banhawy MA, Maguid H M A. AboSaba M A and El-Akkad M M (1992): Ketamine hydrochloride and its implication on the histochemical features of the rat's liver.Egypt.J.Anaesthesiol.,8:23-35.

18. El-Bolkiny Y E (2004): Dose-and timedependent effect of diazepam, an agonist of benzodiazepine receptors ${ }^{\wedge}$ on the liver functions of male albino rats. Egypt. J. Zool., 43:423-437.

19. El-Sherif G, Gobri M S, Zahran W M and Abdel-Hamid $T$ F (2002): 
Histological, histochemical studies and ATP-ase localization in the rat liver after morphine sulphate induction. J. Egypt. Ger. Soc. Zool., 39: 175-187.

20. El-Yamany NA, El-Feki MA, Amin HA and Sawie HG (2002): ameliorative effect of vitamin $\mathrm{C}$ on phenobarbital-induced alterations in some aspects of carbohydrate and lipid metabolism in rats. J. Egypt. Ger. Soc. Zool., 375-398.

21. Flegg HM (1973): An investigation of the determination of serum cholesterol by an enzymatic method. Ann. Clin. Biochem., 10: 79-86.

22. Glantz AS (1992): Primer of biostatist-ics. Mc Graw-Hill, Inc., U.S.A., pp. 2-18.

23. Gomaa HF (2003): Protective effect of certain antioxidants from the nephrotoxicity and hepatotoxicity in male albino rats. Thesis. Faculty of Science. Ain Shams University, Egypt.

24. Haschek WM and Rousseaux CG (1991): Toxicologic pathology. Copyright (C) by Academic Press. INC. London and new York.

25. Ikagami $\mathbf{S}$, Tsuchihashi $\mathbf{F}$ and Nishide $\mathbf{E}$ (1991): Changes in lipid components in liver and serum and production of lipid peroxides in liver by organochlorine pesticides in rats. J. Food Hyg. Soc. Japan., 32(4): 284-290.

26. Infante R, Petit D, Polonovski J and Caroli J (1971): Microsomal phospholipid biosynthesis after phenobarbital administration. Experi., 27(6): 640-642.

27. Ismail D A N (2005): Physiological and histological studies on columba livia domestica treated with an insecticide. Thesis. Fac. of Education. Ain Shams Univ.

28. Jones HB, Harbottle SJ and Bowdler AL (1994): Assessment of labeling index of cohorts of the pancreatic islet cell population in phenobarbitone treated male rats using a double immunohistochemical technique for 5-bromo-2-deoxyuridine and pancreatic hormones. Arch.- Toxicol, 69 (1): 52-58.

29. Khalil H M K (2000): Effects of administration and withdrawal of the sedative hypnotic sominal on the structural and functional changes of the liver in albino rats. Ph.D. Thesis, fac. of Girls. Ain Shams Univ.

30. Levier DG, Brown RJX, Mccay TA and Fuchs BA (1993): Hepatic and splenic phagocytosis in female mice implanted with morphine sulphate pellets. J. Pharmacol, Exp. Then, 267 (1): 357-363.
31. Mandal B, Hazra $\mathbf{N}$ and Maity CR (1982): Metabolic and enzymatic changes in rats following high doses of tetracycline, chloramphenicol and trimethor-pim. Ann. Nat. Acad. Med. Sci. India, 18: 146-156.

32. Mansour A, Abdel-Raheem K, ElMossallamy N, El-Yamany $N$ and Mahmoud S (1995): Impact of chronic administration of ethanol and/or phenobarbitone and drug withdrawal on transaminases and proteins in blood and liver of albino rats. J. Egypt. Ger. Soc. Zool., 16 (A): 429450.

33. Martin DW, Mayer PA and Rodwell V W (1983): Harper's Review of Biochemistry. Middle East Eddition, California.

34. Matthew $R$ and Ray $T$ (1999): Anaesthesia and the liver. Physiology, 10 (5): 1-4.

35. Mayer D, Moore MA and Bannasch $\mathbf{P}$ (1983): Influence of phenobarbital on glycogen metabolism of rat liver pretreated with N-nitrosomorpholine. Carcinogenesis, 4 (7): 931.

36. Mazia D, Brewer PA and Alfert $M$ (1953): Cytochemical staining of protein with mercuric bromophenol blue. Boli. Bull, 104: 57.

37. McClintic R (1978): Physiology of the human body. John Wiley and Sons, Inc. New York.

38. More AR and Brown L (1994): General Pathology. Churchill Livingstone, UK, pp. 1-136.

39. Orr JP, Blakley BR (1997): Investi-gation of the selenium status of aborted calves with cardiac failure and myocardial necrosis. J. Vet. Diagn. Invest., (2): 172179.

40. Pearse A G E (1972): Histochemistiy, Theoretical and Applied. Churchill Livingstone, London.

41. Reitman S and Frankel S (1957): A colourimetric method for determination of serum glutamic oxaloacetic and glutamic pyruvic tranaminases. Am. J. Clin. Pathol., 28: 56-59.

42. Rice J M, Diwan BA, HU H, Ward JM, Nims $R \quad W$ and Lubet RA (1994): Enhancement of hepatocarcinogensis and induction of specific cytocrome P. 450dependent monooxygenase activities by the barbiturates, allobarbital, apobarbital, pentobarbital, secobarbital and 5 - phenyl and 5 - ethylbarbituric acid. Carcinogenesis. 15 (2) 395-402. 
43. Sanad SM, El-Nahass EM, Abdel Gawad AM and Al Deeb AM (1997a): Histochemical studies on the liver of mice following chronic administration of sodium barbitone. J. Egypt. Ger. Soc. Zool., 22 (C): 127-165.

44. Sanad SM, El-Nahass EM, Abdel Gawad A M and Al Deeb AM (1997b): Histopathologic effects of sodium barbitone on the liver of mice. J. Egypt. Ger. Soc. Zool., Vol. 22 (C): 1-16.

45. Smis F and Horn M (1958): Some observations on powell's method for determination of serum bilirubin. Amer. J. Clin. Pathol., 29: 412.

46. Tavill AS (1985): Intracellular pathways of protein synthesis and secretion in the hepatocyte. Semin Liver Dis.; 5: 95-109.

47. Trinder P (1969): Determination of blood glucose using glucose oxidase with an alternative oxygen acceptor. Ann. Clin. Biochem., 6: 24-27.

48. Vajdovich P, Szilagyi A and Gaal T (1995): Evaluation of blood lipid peroxidation parameters in CCI4 toxicity in sheep. Acta. Vet. Hung., 34 (4): 423-429.

49. Wahbi AA, El-Dirdiri N and Tag-Eldin MH. (1987): Sevin toxicity to Sudanese
Nubian goats. Bull. Anim. Hlth. Prod. Afr., 35: 35-58.

50. Ward JM, Hagiward A, Anderson LM, Lindsey K and Diwan B (1988): The chronic hepatic or renal toxicity of diethylhexyl phthalate, $v$ acetaminophen, sodium barbital and phenobarbital in male B6C6 Fl mice: Autoradiographic, immunohistochemical and biochemical evidence for levels of DNA synthesis not associated with carcinogenesis or tumor promotion. Toxicol. Appl. Pharmacol. 96: 494-506.

51. Whysner J, Ross PM and Williams GM. (1996): Phenobarbital mechanistic data and risk assessment enzyme induction, enhanced cell proliferation and tumor promotion. Pharmacol. Ther 71(1-2):153-191.

52. Wieland $O$ (1974): Methods of enzymatic analysis. Vol. 1. Acadmic Press, New York, London, pp. 120-130.

53. Wright R, Willward-Sadler G H, Albert $K$ and Karran S (1985): Liver and biliary diseases. $2^{\text {nd }}$ ed. London. Bailliere Tindall/WB Saunders.

54. Zollner $\mathbf{N}$ and Kirsch $\mathbf{K} \mathbf{Z}$ (1962): Microdetermination of lipids by sulfophosphovanillin reaction. Z. Gez. Exp. Med., 135: 545-560. 


\section{باربيتال الصوديوم أحلث تغيرات بيوكيميائية ونسيجية وكيمونسيجية فى كبا الفار الأمهق}

\section{شادية على رضوان*، عزيزة محمد الوسيمى*، سامية محمد صقر *، سميرة السيد

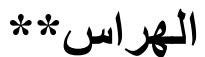

* قسم العلوم البيولوجية و الجيولوجية ـ كلية التربية ـ جامعة عين شمس التهو

** المعهد العالى للفنون التطبيقية بمدينة 6 أكتوبر التربية

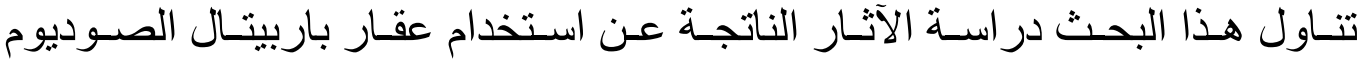

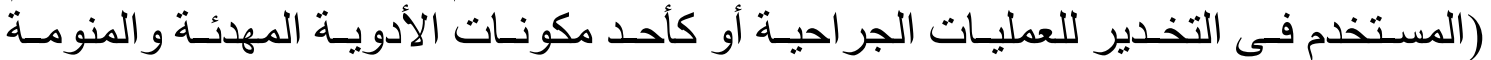

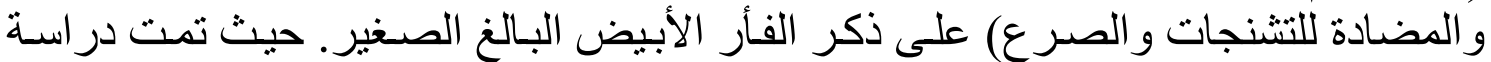

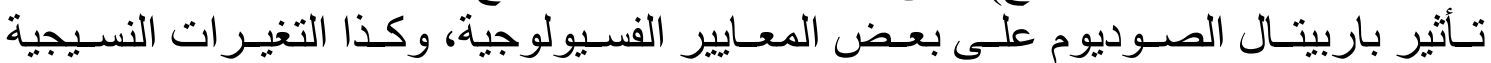

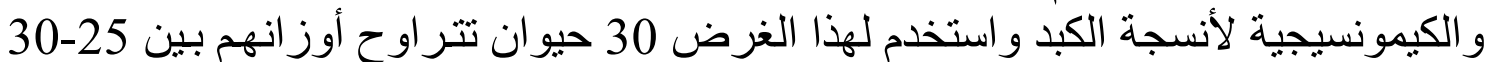

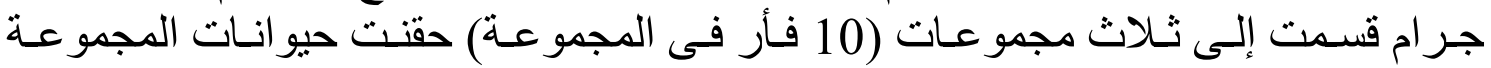
الضـابطة بمحلول ملحى متعادل (0.09\% NaCl ) واعتبرت مجمو عـة ضـابطة بينما حقنت

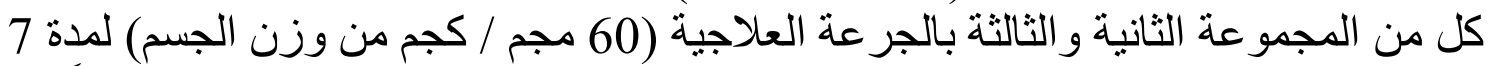

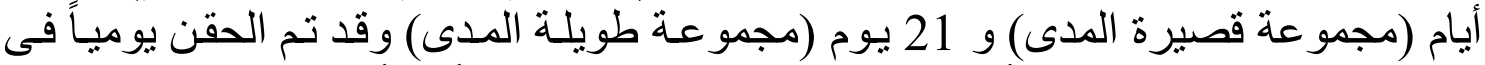

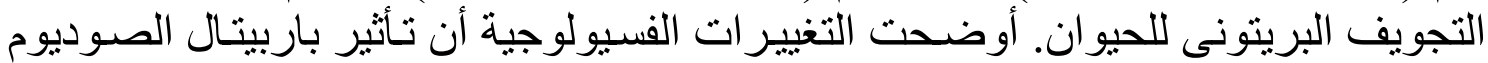

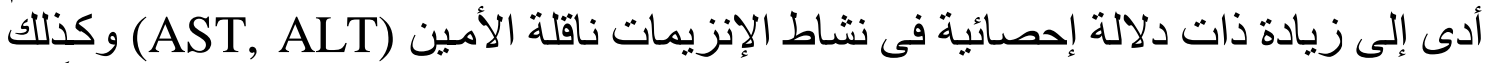

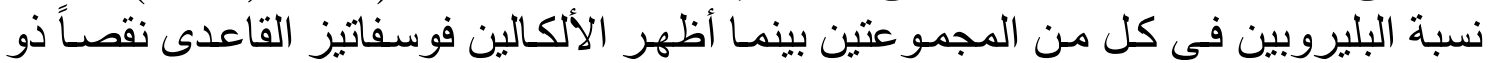
دلالة إحصائية فى كل من المجمو عتين، كما أوضحت فن الدر اسة إرتفاع ذو دلالة إحصائية فى في فئي

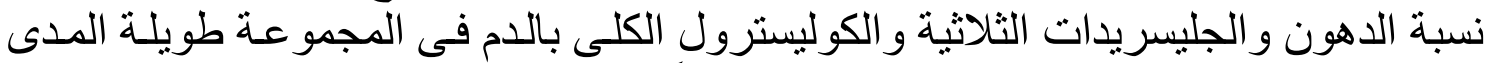
بينما انخفضت نسبة الكوليسترول في الدم إنخفاضاً ذو دلالة إحصائية فى المجمو عـة قصيرة الميرة

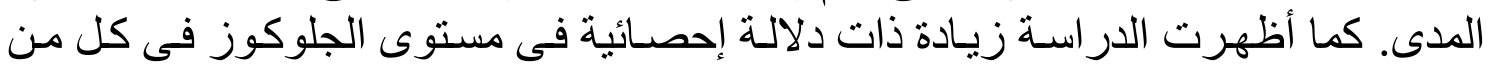
المجمو عتين بالمقارنة بالمجمو عة الضابطة.

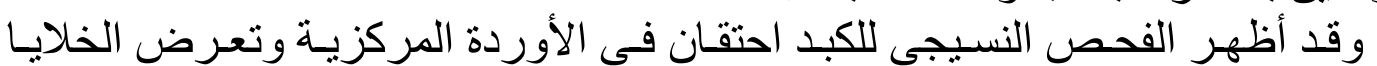

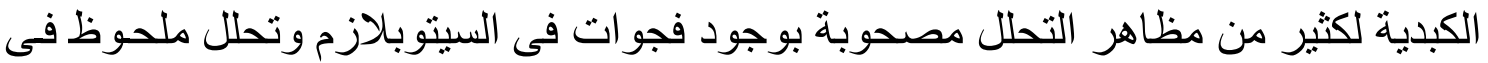

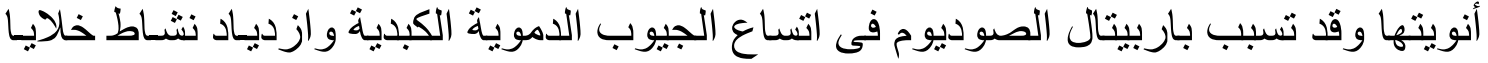

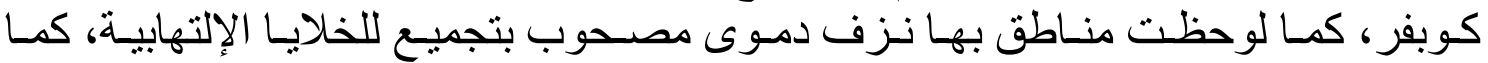

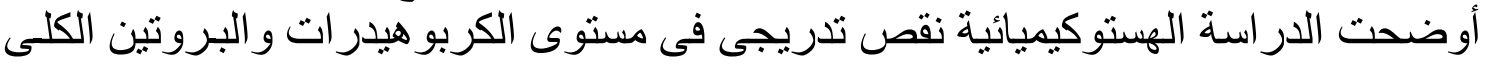
فى نسيج الكبد فى كل من المجمو عتين. 